\title{
THE LEGISLATIVE OMBUDSMEN
}

\author{
ALEX B. WEIR*
}

The Ombudsman institution continues its world wide expansion. The author, who has been Solicitor for Alberta's Ombudsman since May 1,1968, offers an in-depth analysis of the role of a Legislative Ombudsman, with emphasis on the Canadian scene.

There is nothing static in our changing world and recent research has tended to show that the Abominable Noman is being replaced by the Prohibitive Procrastinator. . . . DELAY IS THE DEADLIEST FORM OF DENIAL. This is the Law of Delay. . . . Parkinson's Law of Delay cannot of course be avoided; it is as inevitable as the Law of Gravity. But just as it was within the bounds of human ingenuity to accomplish human flight so, perhaps, there will always be a right way of getting new ideas off the ground. ${ }^{1}$

C. Northcote Parkinson gained world-wide recognition for his lectures dealing with bureaucracy at all levels. His conclusions are scholarly, based on detailed research, statistically reproduced. Nevertheless, the general acceptance of his position has probably been strengthened simply because he appears to echo encounters with bureaucracy that most individuals have had to face.

A new method available in Canada to combat "Parkinson's Law of Delay" is the Ombudsman institution. ${ }^{2}$ The Ombudsman has focused attention to injustice caused by delay. In his last Annual Report to the Alberta Legislature, George B. McClellan said: ${ }^{3}$

Probably the greatest single source of public irritation with Government administration I
have encountered, stems from delays in answering correspondence from the public-or
worse no reply at all. . . I can endorse the justification for such complaints, for I have
exactly the same trouble myself with some Government departments. Repeatedly, I am
forced to send follow up letters; not once but several times; to obtain an answer to my query.
Service more, than a firm insistence on speedy replies to mail received, and prompt
attention to complaints. The present situation can only help to justify a fairly common
impression, that Government is inaccessible to the public.

Similar sentiments have been expressed by other Provincial Ombudsmen in Canada. Complaints of delay usually receive preferential treatment from the Ombudsmen. The administration has appropriately responded to the Ombudsman's approach, resulting often in new procedures, aiding not only the Ombudsman's complainant, but others facing similar circumstances in the future.

Nevertheless, problems created by delay represent simply one challenge facing the Ombudsman. The most serious adversary would be the computer age and its related credit card syndrome that has plunged into our society. Dr. Randall Ivany, Alberta's present Ombudsman, referred to this dilemma by saying: 4

Those of you who have tried to fight against the computer will know what I mean when I refer to the dehumanization process that is an integral part of such a computer age. The computer will wear down human defences unless someone can get to the person who feeds the government computer. Believe me, I can.

* Solicitor, Office of the Alberta Ombudsman.

1 Parkinson, The Law of Delay, Interviews and Outerviews, at 118, 119 and 125.

2 Alberta appointed George B. McClellan on Septem ber 1, 1967, the first Legislative Ombudsman in North America.

3 McClellan, Annual Report 1973, at 15.

- Contained in a speech given by Dr. Ivany to a University of Alberta Administrative Law class, October 8, 1975. 
Investigations reveal not simply where the buck stops but often where the buck starts. Occasionally, situations are uncovered where it is difficult to precisely identify the division of Government ultimately responsible for an apparent injustice. Perhaps there is a sufficient break in the lines of communication revealed on the various Departmental files to prevent establishing responsibility favouring a complainant. The Ombudsman may consult any Minister of the Crown and in due course, submit a recommendation to the Executive Council without necessarily apportioning the degree of responsibility caused by the several Departments involved. In this way, the administrative injustice caused to the complainant, not capable of being assessed directly against the specific Department, may be accepted by the entire Government. Fortunately, the Ombudsman does not have to rely on strict rules of law, by references to court cases, to win his point. The Legislature has authorized the Ombudsman to pursue his complainant's case when satisfied a civil servant was "wrong."

Obviously the Ombudsman institution cannot eliminate all injustice, for in the final analysis, it is only the administrator who may order corrective action. Recognizing this obvious fact, the eight Provincial Legislative Ombudsmen in Canada ${ }^{6}$ have adopted a low key diplomatic approach. It was never intended by the Legislative craftsmen in question for the Ombudsman institution to become an all inclusive cure-all for society's ills. Other avenues of review were not cancelled by the creation of the Ombudsman institution. However, confusion has arisen concerning the role of the Legislative Ombudsman, due in large measure to the appearance of other institutions, similar in name only.

The public support and encouragement given to the Ombudsman institution for rectifying injustice has without doubt resulted in the present world-wide expansion. The current status could hardly have been envisaged back in 1809 when the Ombudsman institution originated in its modern form in Sweden. As there is no uniformity in the legislative and administrative processes throughout the world, it is not surprising that the Ombudsman institution was individually designed to meet local conditions. In Sweden, for example, the Ombudsman may investigate court matters, even concerning himself with the role of the presiding judge. In Canada, the Provincial Ombudsmen are, in the main, restricted to Provincial administration, although in the case of Nova Scotia, local matters may also be investigated.

As this growth in the Ombudsman institution continued, there appeared offices similarly named, but with no truly effective investigative authority. Many appeared more like a public relations office. One Canadian university saw fit to establish an office to improve the relationship between the students and the university cafeteria. The university student appointed was apparently responsible, in a part-time job, to improve that university food service by accepting complaints. Although his official title was "Food Services Ombudsman," it turned out in some of his correspondence, the title was abbreviated to read "Ombudsman." In some cases, the particular service labeled "Ombudsman" has obtained significantly more media coverage than could possibly be obtained through the reasonable efforts of a Legislative Ombudsman.

Dr. Bernard Frank, Chairman of the Ombudsman Committee of the

- The Ombudsman Act, R.S.A. 1970, c. 268, s. 20(1)(d).

- Only British Columbia and Prince Edward Island have not established the Ombudsman institution. 
International Bar Association, provides the following definition for the traditional Legislative Ombudsman: ${ }^{7}$

It is unfortunate that the term 'Ombudsman' has been and is increasingly used throughout the world to mean any complaint-handling mechanism whether governmental or nongovernmental. This is particularly true in the United States. The International Bar Association Resolution makes it clear that the term should be applied only to those officials who come within the definition: An office provided for by the constitution or by action of the legislature or parliament and headed by an independent, high-level public official who is responsible to the legislature or parliament, who receives complaints from aggrieved persons against government agencies, officials, and employees or who acts on his own motion, and who has the power to investigate, recommend corrective action, and issue reports.

The Legislative Ombudsman is appointed by a Legislature and must account to that body alone. This major issue of the Ombudsman's independence from Government control arose historically in Alberta. Early in his career, George B. McClellan was served with a subpoena to appear before a Public Inquiry, established by the Government of the day. That subpoena required Mr. McClellan to give evidence touching on the subject matter of the inquiry relating to one of the Ombudsman's cases and it further stated that he was required to produce any writings or documents in his possession or under his control, relating to that subject matter. Although personally appearing before the Inquiry, Mr. McClellan refused to submit voluntarily to the control of the Commissioner, as directed by the subpoena.

The Inquiry was advised of the appropriate provisions in The Ombudsman Act. By section 23(2) the Ombudsman could not be called to give evidence in any court or in any proceedings of a judicial nature respecting his work. Subsections 3 and 4 of that same section refer to the fact that any document, paper or thing produced by any person in the course of an inquiry by the Ombudsman is privileged. In subsection 1 of the same section, the Legislature directed that no proceedings lie against the Ombudsman regarding any of his reports. Secrecy of the Ombudsman's work is further emphasized by sections 16(1) and 19(1). After referring to the oath of office that must be taken by the Ombudsman, section $9(1)$ then goes on to state that the Ombudsman must not divulge any information received by him under the Act except in official reports made pursuant to the Act, and none of those levels referred to in the Act contemplated such a Public Inquiry. With the exception of a perjury trial, section 17(6) of the Act makes it clear that no statement made or answer given in the course of any proceedings before the Ombudsman is admissible in evidence against any person in any court or in any inquiry or in any other proceedings, and that no evidence in respect of proceedings before the Ombudsman shall be given against any person. $\mathrm{Mr}$. McClellan took the position that that section questioned the admissibility of some of the evidence that may have been presented before the Inquiry. In section 29, there is the legislative direction that The Ombudsman Act is not subject to, but is in addition to the provisions of any other Act; and it was argued that for that reason, the Ombudsman could not be bound by the direction of a Commissioner appointed under The Public Inquiries Act. Finally, section 22 of the Act provided that no proceedings of the Ombudsman shall be held back for want of form and with the exception relating to jurisdiction, indicated no proceedings or decision of the Ombudsman shall be challenged, reviewed, quashed, or called in question in any court. 
It was the firm opinion of Mr. McClellan and so argued before that Inquiry, that aside from the statutory provisions, that a dangerous precedent affecting the independence of all Legislative Ombudsmen was at issue. Mr. McClellan felt very strongly that no Government should be in a position to, at any time, even temporarily deflect the Ombudsman from the channel to the Legislature by such an Inquiry called by the Government.

After providing an opportunity for all counsel to be heard, the Commissioner of that particular Inquiry, The Honourable Mr. Justice C. C. McLaurin, stated: ${ }^{8}$

I haven't any, I haven't any authority to compel Mr. McClellan to give evidence, we will just close this matter, this Inquiry can get along very well if he is not going to give evidence.

Subsequently, the Ombudsman was given the opportunity to appear before the Legislature, in answer to a question put to him by the Leader of the Opposition, who, at that time, was Mr. Peter Lougheed. Mr. McClellan said: 9

As for the concern of the Servant of the Legislature, if I have reiterated this, if I have emphasized this, it is because I feel so very strongly about it, and this is my deep concern that the Ombudsman-not me, not George McClellan, but the institution as a whole, that there should never be any doubt that this is his final court of appeal. He is the Servant of the Legislature, he can only be called to account by the Legislature. With that he can work in confidence because he knows when he gets here, this is the end of the road and whatever the decision is, whether he likes it or not, he has had his decision and he must in good faith then go and carry on his work regardless of what happens. But if there is introduced, and again I say I am asking for reconsideration-anything that deflects him from the Legislature then I would be gravely concerned.

The Alberta Legislature established an amendment to The Ombudsman Act by chapter 75, Statutes of Alberta 1972. This Legislative amendment confirmed the independence of the Ombudsman by stipulating that the Ombudsman shall not be made the subject of an Inquiry under The Public Inquiries Act or be made the subject of an Inquiry, investigation, review, or hearing by any person or body pursuant to any other Act, unless of course as otherwise specifically directed by the Legislative Assembly itself. The independence of a Legislative Ombudsman from possible Government direction was thereby preserved in Alberta, arising from the Philipzyk Case. ${ }^{10}$

The Philipzyk Case is also historically significant by other developments. Mr. R. J. Philipzyk commenced court action and was successful before the Appellate Division of the Supreme Court of Alberta. The Supreme Court of Canada declined to hear a further appeal from that decision. Gordon S. D. Wright, representing Mr. Philipzyk before the courts, indicated that the court's ruling was a "vindication" of the Ombudsman's ruling. He advised the media further that the case now goes back to the Trial Division of the Alberta Supreme Court for assessment of damages and costs.

Professor Karl Friedmann of the University of Calgary, conducted a number of surveys dealing with the Ombudsmen both here and in Britain. He emphasized that although the Ombudsman was not successful in winning Philipzyk's battles, nonetheless, the Ombudsman did achieve a victory. Professor Friedmann's surveys established that many Albertans were right behind the Ombudsman, because he refused to knuckle under. Professor Friedmann indicated that many individuals contacted in

- McLaurin Commission of Inquiry, Volume VII, at 43.

9 Alberta Hansard, April 26, 1971 at

10 Philipzyk v. Edmonton Real Estate Board Cooperative Listing Bureau Ltd., (1975) 55 D.L.R. (3d) 424. 
connection with those surveys strongly supported the Ombudsman's stand, even though they had not personally made a decision one way or another as to whether or not Philipzyk had been subjected to an injustice.

Professor Friedmann concluded from his survey as follows: ${ }^{11}$

As far as his impact on the public service is concerned, the Ombudsman had been successfully transferred to Alberta and is useful in improving the relationship between the citizen and government.

A Provincial Legislative Ombudsman is generally authorized to investigate all administrative matters at the Provincial Government level. McClellan's Law, coined during the Philipzyk investigation, appears to cover this point by stating: "Wheresoever a public servant goes in the performance of his duties, there also may go the Ombudsman." Jurisdictional decisions must be made by the Ombudsman on a daily basis. Fortunately, many such decisions may be made with dispatch. Obviously a Provincial Ombudsman may not investigate complaints directed solely at the Federal Government.

However, there are matters involving the interaction of several Government levels. One such complaint reported in detail in the 1973 Annual Report by the Alberta Ombudsman ${ }^{12}$ concerned the complaint about alleged inadequate boating regulations on a small Alberta lake. According to the complainant, the lake was totally unsuitable for high speed motor boats and numerous water skiers. At first glance it appeared that this matter solely involved the Federal Government pursuant to The Canada Shipping Act and the Criminal Code of Canada. Nevertheless, investigation revealed that the Provincial Government officials had been actively involved in this case that had initially been raised by the complainant in his letter directed to the Provincial Secretary's Department back in August of 1965. During the intervening years the problem became intensified because of the phenomenal increased interest in boating. Recreational water areas have obviously become more and more crowded. As the ultimate responsibility for action appeared to rest with the Federal Government authorities, the Alberta Ombudsman did not feel he was in a position to recommend any specific course of action, apart from encouraging the Provincial Government administration to continue its efforts to resolve the problem faced by the complainant and other residents of the area in question.

There have been instances where the Ombudsman's jurisdiction has been challenged and the courts have been asked to resolve the legal issue. The first major issue involving the jurisdiction of the Alberta Ombudsman was whether or not the Ombudsman was authorized to investigate the Workers' Compensation Board. The Board felt that it was not an agency of Government within the meaning of The Ombudsman Act. The Legislature specifically amended The Ombudsman Act, clarifying that issue by stipulating that the Workers' Compensation Board would be considered an agency of Government for the purposes of an investigation pursuant to The Ombudsman Act, thereby eliminating the need for a court application.

The first reported court case dealing with the jurisdiction of a Legislative Ombudsman arose in Alberta. It was contended that the Ombudsman had no authority to investigate the formal decision handed down by the Provincial Planning Board. The Honourable Chief Justice J. V. H. Milvain

\footnotetext{
1" Friedmann, Controlling Bureaucracy, Attitudes of the Alberta Public Service Towards the Ombudsman, 1975, at 42.

12 McClellan, Annual Report 1973, at 139-140.
} 
of the Alberta Supreme Court Trial Division fully endorsed the position taken by the Ombudsman, and at the same time provided guidance as to the role of an Ombudsman. The Chief Justice stated: ${ }^{13}$

I am satisfied that the basic purpose of an Ombudsman, is provision of a 'watch-dog' designed to look into the entire workings of administrative laws.. . . He can focus the light of publicity on his concern as to injustices and needed change. It must, of course, be remembered that the Ombudsman is also a fallible human being and is not necessarily right. However he can bring the lamp of scrutiny to otherwise dark places, even over the resistance of those who would draw the blinds. If his scrutiny and observations are wellfounded, corrective measures can be taken in due democratic process, if not, no harm can be done in looking at that which is good.

Subsequently, another issue was referred to the courts by the Saskatchewan Ombudsman. That case dealt with the question of whether or not the Royal Canadian Mounted Police is an agency of Government within the meaning of the Provincial Ombudsman legislation. The Saskatchewan court ruled the Royal Canadian Mounted Police is not an agency of the Provincial Government and that appears to settle the legal point, for the time being at least. ${ }^{14}$ Prior to that court case, the Ombudsmen took the position that the agreement entered into between the Federal and Provincial Governments with respect to the operations of the Royal Canadian Mounted Police meant that the police organization became a Provincial police force, with the exception of Royal Canadian Mounted Police investigations under Federal narcotics legislation and similar Federal legislation.

More recently, the Manitoba Ombudsman sought the opinion of the court with respect to a further jurisdicational issue. A District Advisory Planning Commission had challenged his jurisdiction. The complaint concerned a developer who wanted to build a hotel on a parcel of land near a particular community and was refused permission by the Commission. The Manitoba courts confirmed the Ombudsman's jurisdiction to proceed with his investigation. ${ }^{15}$

Another Canadian court case that appears to affect the jurisdiction of the Provincial Ombudsmen was decided by the Federal courts. The case arose in New Brunswick involving the New Brunswick Mental Board of Review, established pursuant to the Criminal Code of Canada. It was argued that the court had no jurisdiction to decide the case inasmuch as it was confined exclusively to Federal Government agencies. The court ruled that it had jurisdiction to decide the case, concluding that the Board was indeed a Federal agency and not an agency of the Provincial Government. ${ }^{16}$ Although that particular court case was not specifically dealing with the New Brunswick Ombudsman Act, the case has strongly influenced the position of the Provincial Ombudsmen with respect to such issues. However, a subsequent decision of the Federal Court of Appeal, delivered on June 6,1975, decided (but for other reasons) that the Federal Court has no jurisdiction to involve itself in such cases. ${ }^{16^{a}}$

Dr. Randall Ivany summed up his concern about references to the courts on jurisdiction as follows: ${ }^{17}$

\footnotetext{
13 Special Report No. 1 of the Ombudsman, 1970, at 16 and 19, and Re Ombudsman Act, (1970) 72 W.W.R. at 176.

"Re Ombudsman Act [1974] 5 W.W.R. 176.

is Unreported decision of the Queen's Bench, delivered on Nov. 20, 1974; referred to in the C.B.A. National, Dec. 1974, at 3.

161973 F.C. 861.

1saLingley v. N.B. Board of Review, No. A-250-74, June 6, 1975 (F.C.A.).

17 Address by Dr. Ivany to the 1975 Canadian Ombudsman Conference.
} 
Hopefully if such jurisdictional issues arise in the future they may be resolved one way or another by the Legislature, for I am frankly not too keen in spending office time in the courts. Obviously such court cases are very time consuming, but apart from that, I simply wish to investigate, as an officer of the Legislature, the type of cases the Legislature has in mind for me. I certainly wouldn't wish to convey an impression that I am seeking jurisdiction that has not been entrusted to me by The Ombudsman Act, yet, on the other hand, I naturally wish to investigate all legitimate complaints within my jurisdiction. Incidentally, a Select Committee of the Legislature will be established this coming fall to deal with the possibility of increasing my jurisdiction with briefs being invited from the general public in that regard.

All of the Provincial Legislative Ombudsmen are presented with comparable challenges to assist individuals in their dealings with Provincial bureaucracy. It is impossible to state categorically and with mathematical precision, the achievements of the Ombudsman institution. Statistics have been compiled that do give a rough indication of the workload of an individual Ombudsman. However, no Provincial Legislative Ombudsman in Canada has recorded the total hours required for each individual investigation. Furthermore, some Ombudsmen include oral complaints in their statistical totals which accordingly complicates comparisons made with Ombudsmen who record for statistical purposes, only complaints that have been received in writing. 18

In his first Annual Report to the Alberta Legislature, Dr. Ivany reported having received a total of 933 complaints and in view of the carry-over of some complaints from the previous year, there was a total of 1,014 cases completed. A total of 320 of those cases were fully investigated of which 120 were considered justified complaints directed against a department or agency of the Provincial Government. A total of 155 complaints were still under investigation at the close of the fiscal year and the remaining complaints were considered outside the Ombudsman's jurisdiction or declined because other avenues were available to the complainant, apart from the intervention of the Ombudsman. There were a total of 5,467 complaints received by the Alberta Ombudsman from September 1, 1967 up to and including October 31,1974 . Looking at the statistical results from the percentages point of view, $26.30 \%$ of the cases investigated were considered justified complaints during that entire period, and during Dr. Ivany's first reporting year to the Legislature, $30 \%$ of the complaints were considered justified.

Most Legislative Ombudsmen in Canada have rectified complaints dealing with the following issues: insufficient assistance provided, including welfare and other forms of compensation; adoption and foster children matters; Government intervention with respect to alleged child abuse; the administration of estates by Government officials; the numerous licensing and lease programs; the construction of public works; decisions affecting the career development of any Provincial civil servant; numerous issues raised by individuals confined in Provincial institutions; and indeed, the entire gamut of Provincial Government involvement. In some cases, the financial settlement correcting the injustice involves thousands of dollars, some being considerably in excess of $\$ 10,000$ for the individual complainant.

For the most part, senior Government officials work together with the Ombudsman to achieve a suitable solution, fair to all concerned.

in Nova Scotia and New Brunswick Ombudsmen Reports currently include references to oral complaints in their statistical summaries. 
Understandably the results are easiest to calculate, upon studying the benefits accruing to the complainant. Nevertheless, some cases result in significant procedural changes designed to help other individuals in the future. For instance, in one case involving the Alberta Workers' Compensation Board, the complainant received $\$ 4,570$. This was achieved after the case was referred by the Ombudsman to the Executive Council. Before that case was rectified, an amendment was established by the Alberta Legislature authorizing that form of intervention by the Executive Council, upon accepting the recommendation of the Ombudsman. ${ }^{19}$ The Alberta Ombudsman had been placed in a most advantageous position of being able to assist in this specific area.

Although the Legislative Ombudsmen usually adopt very informal procedures during their investigations, there are some rare exceptions. There is Legislative authority for basically two types of formal hearings that may be established by the Ombudsman. The Manitoba Ombudsman, Mr. George Maltby, reported details of one hearing where the witnesses were summonsed and their testimony provided under oath. Mr. Maltby said:20

After my initial questioning of witnesses, I realized I was not getting the facts and I was determined to do just that. I therefore invoked section 30(2) of The Ombudsman Act and summonsed witnesses to appear before me to testify on oath.

At the conclusion of that case comment, Mr. Maltby indicated that the matter was rectified from the complainant's point of view, not as a result of any recommendation made by the Ombudsman, but simply as a direct result of the Ombudsman conducting an investigation.

Another type of hearing before the Ombudsman is contemplated by the provisions of section 26(3) of the Alberta Ombudsman Act and comparable legislative authorities contained in the legislation governing most other Legislative Ombudsmen: ${ }^{21}$

26(3). The Ombudsman shall not, in any report made under this section, express any opinion or make any comment that is adverse to

(a) any department or any officer or employee of a department, or

(b) any agency or any member or employee of an agency, or

(c) any other person or group of persons, unless prior to making the report to the Legislature or publishing the report pursuant to subsection (2), as the case may be, the Ombudsman had given that department, agency, officer, member, employee, person or group of persons an opportunity to know the nature of the opinion or comment and to make representations to him in respect of it either personally or by counsel.

So far, at least, all hearings held by the Alberta Ombudsman pursuant to section 26(3), just recited, have been conducted informally, for no witnesses have ever been subpoenaed to appear before the Alberta Ombudsman and no witness has, so far, been required to testify under oath before the Alberta Ombudsman.

During conferences, the Legislative Ombudsmen compare their respective work experiences. There are some noticeable and dramatic differences in the type of complaint investigated. On the Alberta scene, there have been a number of investigations involving expropriations and reclamation problems directly involving the oil industry. The Quebec Ombudsman faced a most unique situation involving the implementation of The War Measures

\footnotetext{
iy McClellan, Annual Report 1972, at 110-113.

so Maltby, Report of the Ombudsman, 1973, at 65.

2 R.S.A. 1970, c. 268, s8. 20 and 26 ; 1972 , c. 75 , s. 8.
} 
Act dealing specifically with law and order. Many complainants sought the assistance of Dr. Louis Marceau due to their arrest and detention without trial. His investigations were so extensive in that area that he had to temporarily hire several additions to his staff.

The Canadian Legislative Ombudsmen have accelerated their efforts of mutual cooperation and exchange of ideas. At their recent Conference, the Saskatchewan Ombudsman, Mr. Ernest Boychuk, was appointed as the Canadian Ombudsman's Secretariat. Information about jurisdictional court cases and unique situations will be referred to him and he in turn will accordingly advise all the Canadian Legislative Ombudsmen. The Legislative Ombudsmen have also proposed the establishment of a center for Ombudsman studies at a Canadian university or other suitable location. Such a center was considered as useful to study and research all material information relating to the Ombudsman institution in general with the hope that seminars and courses could later develop. Further details regarding such a project will be discussed and hopefully finalized at the 1976 Conference scheduled for Alberta. Incidentally, at the request of the Ombudsmen from the Pacific Corridor, this Conference will take on an international status. It is expected that approximately 50 delegates will be attending this International Ombudsman Conference. $A$ number of academics who have distinguished themselves for their interest in the Ombudsman institution will be invited to that Conference as well as Legislative Ombudsmen from various parts of the world.

Close ties and extensive cooperation have been maintained among the Ombudsmen. Besides periodic conferences, the Ombudsmen have exchanged their Annual Reports and other written communications outlining their respective ideas and novel experiences. Such communications among the Ombudsmen assist in eliminating otherwise unproductive efforts that could, for example, be caused by a duplicate research project carried out independently and simultaneously by two Ombudsmen. One research program initiated by the Alberta Ombudsman involved the collection of data from past case files in certain specified areas, compiled through the cooperation of the Data Center. Considered a relatively simple project by computer programming standards, it was nonetheless, a major project. Retained for two summer sessions, the project was carried out by a University of Alberta Law student, Mr. Randolph Langley. The information stored in the computer cards may be retrieved as required by the Ombudsman to provide an overview of various complaint categories, such as inmate complaints, or the statistical results could be used as a foundation for other possible research projects. The confidential nature of all files would obviously necessitate the Ombudsman's close personal scrutiny of any use of this computer program.

The Ombudsman institution must certainly be prepared to adapt to necessary change. Traditionally, the Legislative Ombudsmen have adopted the low key diplomatic approach. There are those who have publicly charged that an Ombudsman can only be effective by adopting the flamboyant and spectacular working style generally attributed to individuals like Mr. Ralph Nader. Mr. Nader has unquestionably gained strong public support for his achievements as a self-appointed consumer advocate. Nevertheless, the Canadian Legislative Ombudsmen have unanimously agreed that at least for them, the appropriate working style must be the low key approach. They have concluded that at this given point in time a dramatic change in the 
working style of the Ombudsman might well mean that many borderline cases would not be voluntarily rectified by Government.

The future working style and authority of the Ombudsman institution will likely be adjusted. Changes are indeed inevitable, and the institution must ready itself to meet the challenges that lie ahead. The Ombudsman institution has the flexibility sufficient to be a dynamic influence on our turbulent society.

The Supreme Court of Canada duly recognized the contribution of the Canadian Legislative Ombudsmen by inviting them to attend, as guests, the Supreme Court of Canada Centenary Symposium. Such a birthday celebration was a splendid occasion for the eight Provincial Ombudsmen to informally meet members of the judiciary, law deans and distinguished members of the legal profession and academic world. The mutual respect shared between the legal profession and the Ombudsman institution is certainly not a recent innovation. The Canadian Bar Association had urged the establishment of the Ombudsman institution within Canada several years before the Legislative initiative was in fact taken.

Further evidence of this comradeship is suitably illustrated by the recent appointment of Ontario's first Ombudsman, Mr. Arthur Maloney, Q.C. Shifting as one of the best criminal defence lawyers in Canada to this new career, Mr. Maloney was honoured by the capacity gallery during the official installation ceremony at the Ontario Legislature. Speaking about this appointment, former Prime Minister John Diefenbaker, who was among the well-wishers attending the ceremony, described Mr. Maloney and the goal of the Ombudsman as follows: "He (Mr. Maloney) is a great lawyer, a great humanitarian, and a man devoted to justice." Mr. Diefenbaker went on to state that the Ombudsman "will provide a voice for people who have never had a voice."22 Giving this last word to John Diefenbaker appears most appropriate for as Arthur Maloney observed: "For John Diefenbaker there never will be a last hurrah-he will just go on forever."23

22 Article appearing in the Toronto Globe and Mail. October 31, 1975.

4. Address delivered Oct. 30, 1975 by Arthur Maloney on the occasion of his being sworn into office as Ombudsman for Ontario. 